\title{
Hypothalamic Y2 receptors regulate bone formation
}

\author{
Paul A. Baldock, ${ }^{1}$ Amanda Sainsbury, ${ }^{2}$ Michelle Couzens, ${ }^{2}$ Ronaldo F. Enriquez, ${ }^{1}$ \\ Gethin P. Thomas, ${ }^{1}$ Edith M. Gardiner, ${ }^{1}$ and Herbert Herzog ${ }^{2}$ \\ ${ }^{1}$ Bone and Mineral Program, and \\ ${ }^{2}$ Neurobiology Program, Garvan Institute of Medical Research, St. Vincent's Hospital, Sydney, Australia \\ Address correspondence to: Herbert Herzog, Neurobiology Program, Garvan Institute of Medical Research, \\ 384 Victoria Street, Darlinghurst, NSW 2010, Sydney, Australia. \\ Phone: 61-2-9295-8-296; Fax: 61-2-9295-8-281; E-mail: h.herzog@garvan.org.au. \\ Paul A. Baldock and Amanda Sainsbury contributed equally to this work. \\ Received for publication November 8, 2001, and accepted in revised form February 18, 2002.
}

\begin{abstract}
Neuropeptide Y (NPY) is a downstream modulator of leptin action, possibly at the level of the arcuate nucleus where NPY neurons are known to express both leptin receptors and Y2 receptors. In addition to the well-described role of NPY and leptin in energy balance and obesity, intracerebroventricular administration of NPY or leptin also causes bone loss. Here we show that Y2 receptor-deficient mice have a twofold increase in trabecular bone volume as well as greater trabecular number and thickness compared with control mice. We also demonstrate that central Y2 receptors are crucial for this process, since selective deletion of hypothalamic Y2 receptors in mature conditional Y2 knockout mice results in an identical increase in trabecular bone volume within 5 weeks. This hypothalamus-specific Y2 receptor deletion stimulates osteoblast activity and increases the rate of bone mineralization and formation, with no effect on osteoblast or osteoclast surface measurements. The lack of any changes in plasma total calcium, leptinemia, or hypothalamo-pituitary-corticotropic, -thyrotropic, -somatotropic, or -gonadotropic output suggests that $\mathrm{Y} 2$ receptors do not modulate bone formation by humoral mechanisms, and that alteration of autonomic function through hypothalamic Y2 receptors may play a key role in a major central regulatory circuit of bone formation.
\end{abstract}

J. Clin. Invest. 109:915-921 (2002). DOI:10.1172/JCI200214588.

\section{Introduction}

Genetically obese rodents that lack leptin ( $o b / o b$ mice) or its receptor ( $d b / d b$ mice) show increased activity of neuropeptide Y (NPY) circuits in the hypothalamus due to lack of leptin-induced inhibition of NPY expression and secretion (1). Such increased hypothalamic NPY signaling contributes to the massive obesity, hypercorticism, stunted growth, and reproductive defects of these mice (2). Since NPY ablation in $o b / o b$ mice attenuates all of these defects (3), these findings demonstrate that NPY is a downstream mediator of leptin's central effects.

Recently it was shown that leptin can inhibit bone synthesis by action within the hypothalamus, and that mice with no or reduced leptin signaling $(o b / o b$, $d b / d b$, and transgenic A-ZIP/F-1 fat-deficient mice) have high bone density associated with increased bone formation (4). This effect of leptin deficiency occurred independently of increased body fat or body weight, and despite the hypercorticism, decreased somatotropic activity, and hypogonadism in $o b / o b$ and $d b / d b$ mice. Intriguingly, central infusion of NPY for 28 days in wild-type mice had the same inhibitory effect on bone function as leptin had, suggesting that the increased hypothalamic NPY expression of leptin-deficient mice does not mediate the associated increase in bone density (4). However, it is unclear from this study whether the inhibitory effects on bone of central NPY infusion are a direct consequence of hypothalamic NPY action or a secondary effect of the resulting increase in expression (5) and circulating concentrations (6) of leptin. Furthermore, NPY mediates its effects through the activation of at least five different receptors: Y1, Y2, Y4, Y5, and in the mouse also $y 6$, all of which are expressed in the hypothalamus (7-9). The potential for simultaneous activation of all of these receptors by central NPY infusion makes it difficult to distinguish the true role of the different types of hypothalamic Y receptors in bone physiology.

NPY synthesis is particularly high in neurons of the arcuate nucleus, with many of these neurons also expressing leptin receptors (10). A high percentage of these arcuate NPY-expressing neurons coexpress the Y2 receptor (11), which is thought to act as an autoreceptor that can modulate the expression and secretion of NPY and other neurotransmitters (12). Since leptin receptors and $\mathrm{Y} 2$ receptors are present on NPY-expressing neurons of the arcuate nucleus and are likely to share some common signaling pathways $(1,10-12)$, we hypothesized that the Y2 receptor might be involved in the central regulation of bone metabolism. To test this hypothesis, we generated both germline Y2 receptor knockout mice $\left(\mathrm{Y}^{-/-}\right.$ 


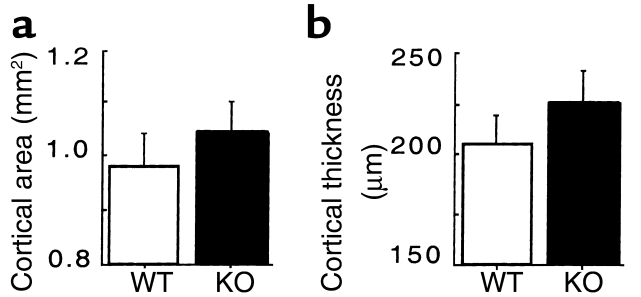

Figure 1

Effect of germline $Y 2$ receptor deletion on cortical bone of the distal femur. Cortical area (a) and cortical thickness (b) of the femoral midshaft of male wild-type mice (WT, white bars) compared with those of $Y 2^{-1-}$ mice (KO, black bars) at 15-17 weeks of age. Values are mean \pm SD of five to eight mice per group.

mice) and conditional Y2 receptor knockout mice $\left(Y 2^{l o x} / l o x\right.$ mice $)$ and investigated the effects of the deletion on bone physiology.

\section{Methods}

Generation of germline and conditional Y2 receptor knockout mice. A targeting vector for the $\mathrm{Y} 2$ receptor gene has been designed that allows the production of both germline $\left(Y^{-{ }^{--}}\right)$and conditional (floxed, $\left.Y 2^{l o x} / l o x\right)$ knockout mice. Both of these knockout strategies result in deletion of the entire coding region of the $\mathrm{Y} 2$ receptor, which is encoded by a single exon. Mouse embryonic stem cells from the strain 129SvJ were transfected and selected under standard conditions, and positive embryonic stem cell clones were injected into blastocysts from C57/BL6 mice. Chimeric offspring were crossed with oocyte-specific Cre-recombinase-expressing C57/BL6 mice (13) in order to obtain either heterozygotes carrying the floxed gene ( $Y 2^{l o x /+}$ mice) or heterozygotes carrying the Cre-recombinase gene with the floxed gene already deleted $\left(\mathrm{Y}^{+/-}\right.$mice $)$. Homozygous lines, both $Y 2^{-/-}$and $Y 2^{l o x} / l o x$, were generated by crossing the respective heterozygous animals. All further mice were maintained on this mixed C57/BL6-129SvJ background.

Adenovirusinjection. $Y 2^{l o x} / l o x$ and wild-type $Y 2^{+/+}$mice, 10-12 weeks old, were anesthetized with $100 \mathrm{mg} / \mathrm{kg}$ ketamine (Pfizer Inc., Sydney, Australia) and 20 $\mathrm{mg} / \mathrm{kg}$ xylazine (Bayer AG, Leverkusen, Germany) and injected with adenovirus expressing either recombinant Cre or green fluorescent protein (GFP) (The Institute of Physical and Chemical Research, Riken, Fukyuka, Japan) using a stereotaxic table (David Kopf Instruments, Tujunga, California, USA). With the head in the flat-skull position, brain injection coordinates relative to Bregma were posterior 2.3 $\mathrm{mm}$, lateral $\pm 0.3 \mathrm{~mm}$, and ventral $5.6 \mathrm{~mm}$, corresponding to the arcuate nucleus (14). One microliter of either virus $\left(10^{9}\right.$ plaque-forming units $\left./ \mu \mathrm{l}\right)$ was injected bilaterally over a period of 10 minutes using a 26-gauge guide cannula and a 33-gauge injector (Plastics One Inc., Roanoke, Virginia, USA) connected to a Hamilton syringe and a syringe infusion pump (World Precision Instruments Inc., Sarasota, Florida, USA). Mice were housed individually for the ensuing 35 days, with ad libitum access to standard chow and water.

Tissue collection and analysis. Mice were injected with the fluorescent tetracycline compounds calcein and demeclocycline $(15 \mathrm{mg} / \mathrm{kg}$ each; Sigma Chemical Co., St. Louis, Missouri, USA) 10 days and 3 days prior to collection, respectively. At 15-17 weeks of age, germline and conditional Y2 knockout mice were killed by cervical dislocation between 1000 and 1400 hours for collection of trunk blood in heparinized tubes, and plasma was immediately frozen. Both femora were excised and bisected transversely at the midpoint of the shaft. The distal halves of the right femora were fixed and embedded, undecalcified, in K-Plast resin (Medim-Medizinische Diagnostik, Giessen, Germany), and 5- $\mu \mathrm{m}$ sagittal sections were prepared for analysis using BioQuant software (R\&M Biometrics Inc., Nashville, Tennessee, USA). Cortical parameters were measured at the bisection point using the proximal portion of the bone. Cortical area was calculated by subtraction of the medullary area from the total bone area, and cortical thickness was calculated by radius difference assuming a perfectly circular shape. Sections were stained for mineralized bone (15), and trabecular bone volume, thickness, and number were calculated (16) in the sample region (see Figure 2). Osteoblast parameters (osteoblast surface, osteoblast number, and osteoid surface) were estimated using sections stained with von Kossa stain and toluidine blue. Only osteoblasts identified adjacent to osteoid surfaces were included in the analysis. Bone formation (mineralizing surface, MS) was estimated using the bone surface (BS) coverage of single- and double-labeled (sLS and dLS) fluorescent bands using the equation $\mathrm{MS}=\{[(0.5 \times \mathrm{sLS})+\mathrm{dLS}] \times 100\} / \mathrm{BS}$, expressed as a percentage of BS. Mineral apposition rate (MAR) was estimated by the distance between the labels divided by the time interval between injection of labels (MAR $=$ interlabel distance divided by 7 , expressed in $\mu \mathrm{m} / \mathrm{d}$ ). Bone formation rate (BFR) was calculated after fluorescence

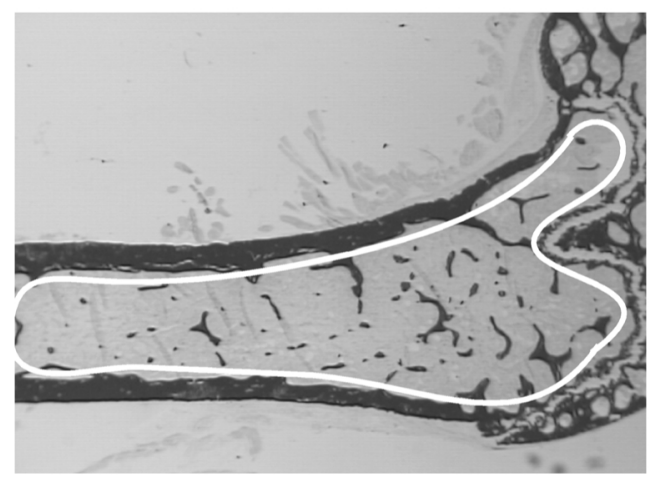

\section{Figure 2}

Sample area for trabecular bone histomorphometry. All trabecular bone bordered distally by the epiphyseal growth plate and extending $4.5 \mathrm{~mm}$ proximally was sampled. 
a

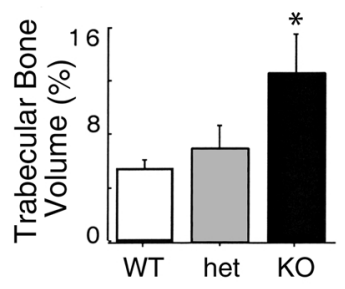

b

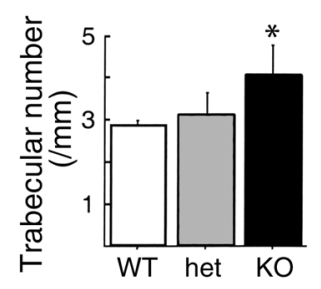

C

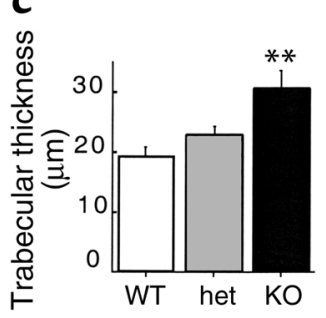

Figure 3

Effect of germline Y2 receptor deletion on trabecular bone of the distal femoral metaphysis. Trabecular bone volume (a), trabecular number (b), and trabecular thickness (c) of femora from male wild-type mice (WT, white bars) compared with heterozygous $\mathrm{Y2}^{+/-}$(het, gray bars) and homozygous $\mathrm{Y}^{-1-}$ mice (KO, black bars) at 15-17 weeks of age. Values are mean \pm SD of five to eight mice per group. ${ }^{*} P<0.05,{ }^{*} P<0.01$ versus wild-type mice. microscopy (Leica Microsystems, Heerbrugg, Switzerland) as BFR $=\mathrm{MS} / \mathrm{BS} \times \mathrm{MAR}$, expressed in $\mu \mathrm{m}^{2} / \mu \mathrm{m} / \mathrm{d}$ ) (17). For measurements of osteoclast surface and osteoclast number, sections were stained for tartrate-resistant acid phosphatase (TRAP) activity as described previously (18), with only multinucleated, TRAP-positive cells included in the analysis. Radioimmunoassay kits were used to determine plasma concentrations of leptin (Linco Research Inc., St. Louis, Missouri, USA), corticosterone, free T4, testosterone (ICN Biomedicals Inc., Costa Mesa, California, USA), and IGF-1 (Bioclone Australia Pty. Ltd., Marrickville, Australia). Plasma total calcium levels were determined using a colorimetric assay kit from Sigma Chemical Co.

In situ PCR. Fresh-frozen coronal brain sections were fixed in 4\% paraformaldehyde in PBS for 30 minutes, washed once (for 5 minutes) in PBS, and treated with proteinase $\mathrm{K}(5 \mu \mathrm{g} / \mathrm{ml})$ for 1 minute at room temperature. Sections were then rinsed for 5 minutes in PBS followed by a 5 -minute wash in $100 \%$ ethanol. After drying the slides, Gene Frames (Advanced Biotechnologies Ltd., Epsom, United Kingdom) were put around each section. One hundred microliters of PCR mix containing digoxigenin-labeled nucleotides and a combination of primers was prepared: oligo $\mathrm{C}\left(5^{\prime}\right.$ TTAACATCAGCTGGCCTAGC- $\left.3^{\prime}\right)$ and oligo D (5'GGAAGTCACCAACTAGAATGG-3') were used to verify the $Y 2^{l o x} /$ lox genotype; oligo $\mathrm{C}$ and oligo $\mathrm{E}\left(5^{\prime}\right.$ AGCATCCAGAGAAGTGCAAC-3') were used to verify the deleted $Y 2^{-/-}$genotype. Each primer mixture was preheated to $65^{\circ} \mathrm{C}$, then added to the sections, which were then sealed off with a self-adhesive plastic cover slip. In situ PCR was carried out using an OmniSlide thermal cycler (Hybaid Ltd., Teddington, Middlesex, United Kingdom), with pretreatment at $95^{\circ} \mathrm{C}$ for $5 \mathrm{~min}$ utes followed by 40 cycles of denaturing at $95^{\circ} \mathrm{C}$ for 1 minute, annealing at $61^{\circ} \mathrm{C}$ for 1 minute, and extension at $72^{\circ} \mathrm{C}$ for 25 seconds. At the end of PCR, the cover slips and Gene Frames were removed and slides were washed for 5 minutes in xylene followed by 5 minutes in $100 \%$ ethanol. Staining to detect the incorporated label was performed as described earlier (8).

Statistical analyses. All data were assessed by factorial ANOVA followed by the Fisher or contrast post-hoc tests, using StatView version 4.5 or Super-ANOVA (Abacus Concepts Inc., San Francisco, California, USA). For all statistical analyses, $P<0.05$ was accepted as being statistically significant.

\section{Results}

Effects of germline Y2 receptor deletion on bone formation. Skeletal phenotypes of $Y 2^{-/-}$mice were analyzed in the femora, and cortical bone parameters were assessed at the midshaft dissection point. There was no significant difference in the cross-sectional area or the thickness of the cortical bone between wildtype and germline $Y 2^{-/-}$mice, although a trend toward increased cortical bone in the knockout animals can be seen (Figure 1). However, trabecular bone volume of the distal femoral metaphysis (sample region shown in Figure 2) was increased twofold in germline $Y 2^{-/-}$mice compared with wild-type animals, with heterozygous mice showing a tendency toward increased trabecular bone volume (Figure 3a). This increased trabecular volume of $Y 2^{-/-}$animals was associated with a significant increase in the number and thickness of trabecular structures (Figure 3, b and c, and Figure 4).

Y2 receptor $\mathrm{mRNA}$ has been found in a variety of central and peripheral tissues $(8,19,20)$. In order to determine whether bone tissue expresses $Y$ receptors through which NPY could directly regulate bone function, we used RT-PCR to investigate the existence of mRNA for all of the five known Y receptors in total bone tissue of wild-type mice or the osteoblast cell line MC3T3 E1. Primers that are specific for each of

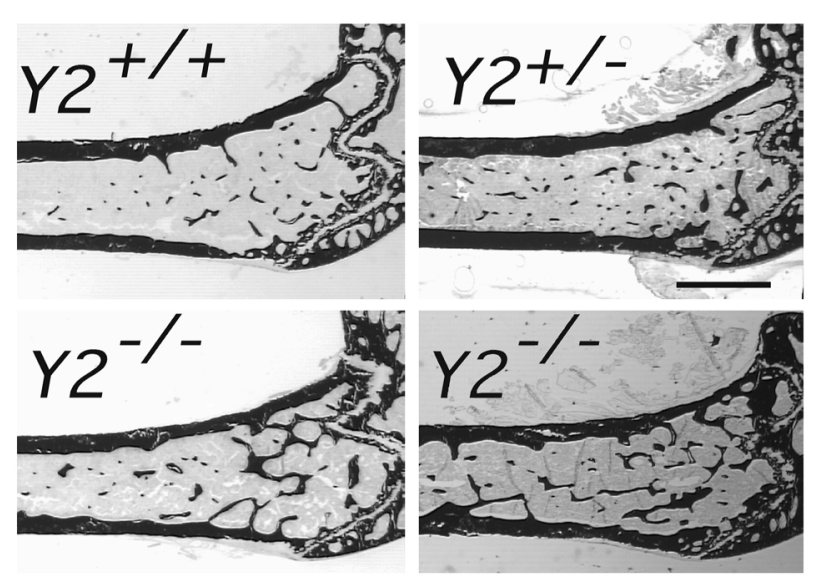

Figure 4

Sagittal micrographs of the distal femoral metaphysis of germline $Y 2^{-/-}$ male mice at 15-17 weeks of age compared with $\mathrm{Y}^{+/-}$and wild-type $\left(Y^{+/+}\right)$control male mice. Figures show darkly stained bone tissue and are representative of the respective groups. Bar represents $1 \mathrm{~mm}$. 

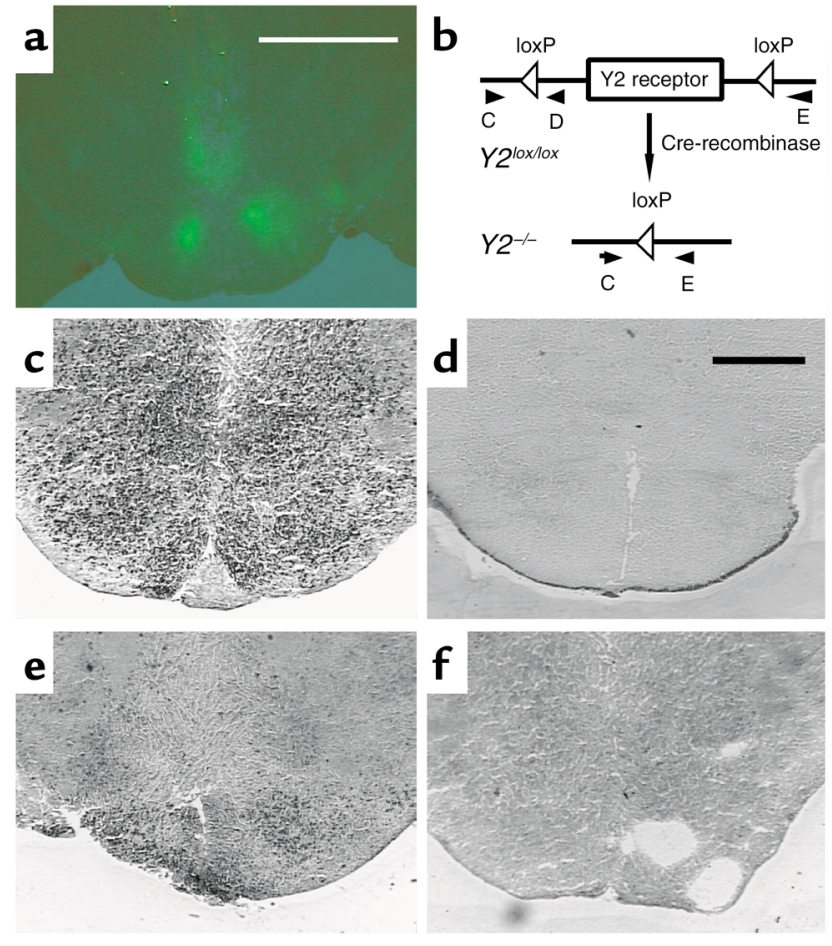

the receptor genes and are located on two different exons were used to ensure that only properly spliced mRNA and not genomic DNA contaminants were amplified. RT-PCR did not yield products specific for any of the $\mathrm{Y}$ receptors in any of these preparations, suggesting that NPY and Y2 receptor deletion influences bone density by receptors in locations other than in bone itself.

Effects of hypothalamus-specific Y2 receptor deletion on bone formation. A possible central role of $\mathrm{Y} 2$ receptors in bone physiology was investigated after selective removal of hypothalamic $\mathrm{Y} 2$ receptors in conditional Y2 receptor knockout mice. Ten- to twelve-week old $Y 2^{l o x / l o x}$ and $Y^{+/+}$mice were bilaterally injected into the hypothalamus with adenovirus expressing either Crerecombinase or GFP, and femurs of these mice were collected 35 days later when mice were 15-17 weeks of age. In these experiments, the two groups of control mice (GFP-injected $Y 2^{l o x / l o x}$ and Cre-injected $\mathrm{Y2}^{+/+}$ mice) were indistinguishable from each other for all parameters investigated, and data were therefore pooled into a single control group for all figures.

\section{Figure 5}

Expression of GFP and in situ PCR of the hypothalamus of Cre-adenovirus-injected $Y 2^{10 x / l o x}$ mice and germline $Y 2^{-/-}$mice. (a) Fluorescence micrograph of the hypothalamus of a $Y 2^{l o x / l o x}$ animal 21 days after injection of GFP-expressing adenovirus. Bar represents $2 \mathrm{~mm}$. (b) Schematic drawing of the position of the primers (oligo C, D, and E) used for in situ PCR. (c) In situ PCR on a brain section from a $Y 2^{10 x / 10 x}$ animal using oligo $C$ and oligo D. (d) In situ PCR on a brain section from a $Y 2^{-/-}$animal using oligo $C$ and oligo D. (e) In situ PCR on a brain section from a Cre-adenovirus-injected $Y 2^{l o x} /$ lox animal using oligo $C$ and oligo $E$. (f) In situ PCR on a brain section from a Cre-adenovirus-injected $Y 2^{l o x} / / 0 x$ animal using oligo $C$ and oligo $E$ without enzyme. Bar represents $1 \mathrm{~mm}$ in $\mathbf{c}-\mathbf{f}$.

Appropriate positioning of the stereotaxic injection coordinates was monitored by the appearance of green fluorescence in the hypothalamus of GFPinjected animals (Figure 5a). Cre gene expression and consequent $\mathrm{Y} 2$ receptor gene deletion in the hypothalamus were confirmed at 35 days after adenovirus injection by in situ PCR analysis of coronal brain sections isolated from these animals (Figure 5, b-f).

The selective deletion of hypothalamic $\mathrm{Y} 2$ receptors in adult mice resulted in a bone phenotype identical to that seen in germline $\mathrm{Y2}^{-/-}$animals. A twofold increase in trabecular bone volume was produced during the 5 -week period of hypothalamic Y2 receptor deficiency (Figure 6a and Figure 7). Consistent with germline Y2 receptor knockout, hypothalamic Y2 deletion resulted in increased trabecular number and trabecular thickness (Figure 6, b and c). There was no indication of change in resorption as measured by osteoclast surface (Figure 8a), but osteoclast number was significantly reduced (Figure $8 \mathrm{~b}$ ). Osteoblast surface, osteoblast number, osteoid surface, and mineralizing surface were all unaffected by hypothalamic Y2 receptor deletion (Figure 8, c-f). However, the rates of bone mineral apposition and bone formation were significantly increased by the hypothalamic Y2 receptor deletion (Figure 8, g and h). This measure of the speed of bone mineralization, as indicated by the distance between the two fluorescent bands, showed that hypothalamusspecific Y2 receptor knockout animals laid down substantially more bone than did control animals (Figure 9). Indeed, bone mineral apposition rate and the associated bone formation rate in the conditional knockouts were both around twofold higher than these rates in controls (Figure 8, $\mathrm{g}$ and $\mathrm{h}$ ).

\section{Figure 6}

Effect of adult induced hypothalamus-specific $\mathrm{Y} 2$ receptor deletion on trabecular bone of the distal femoral metaphysis. Trabecular bone volume (a), trabecular number (b), and trabecular thickness (c) in male $\mathrm{Y}^{+/+}$Cre-adeno-virus-injected or $Y 2^{\text {lox/lox }}$ GFP-adenovirus-injected control mice (white bars) compared with $Y 2^{10 x / 10 x}$ Cre-adenovirus-injected mice (KO, black bars) at 15-17 weeks of age. Values are mean \pm SD of five to seven mice per group. ${ }^{*} P<0.01,{ }^{*} P<0.001$ versus controls.
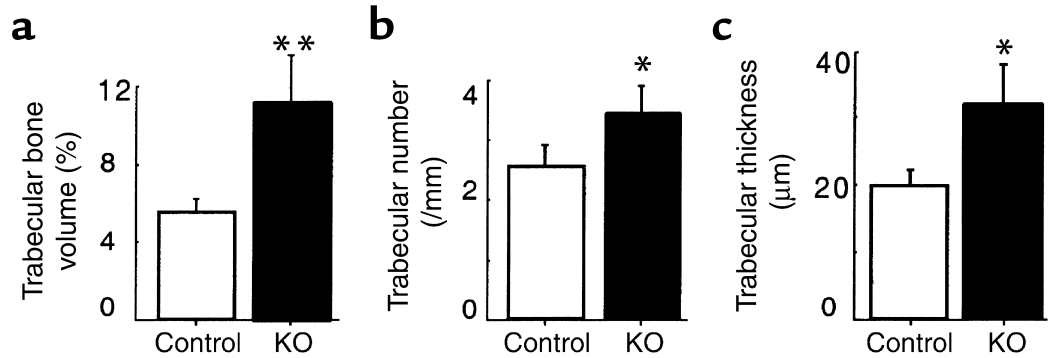

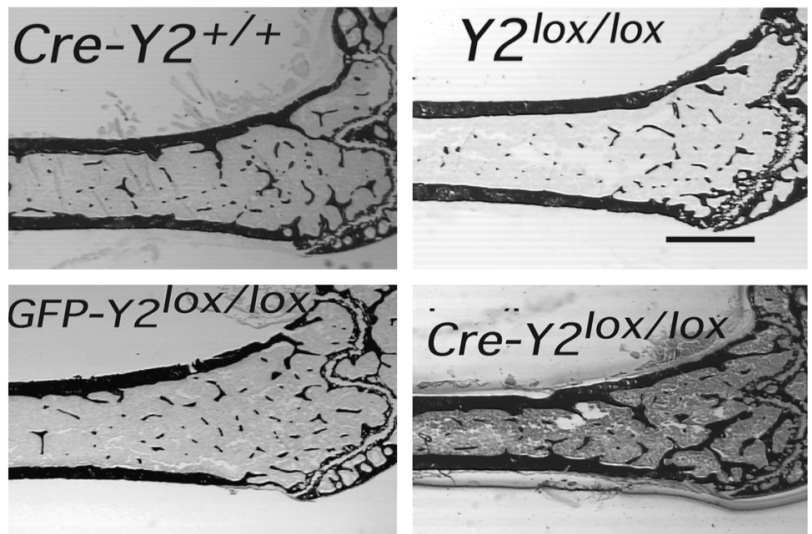

Figure 7

Sagittal micrographs of the distal femoral metaphysis of control and hypothalamus-specific Y2 receptor knockout mice: Creadenovirus-injected wild-type control $\left(\mathrm{Cre}-\mathrm{Y}^{+/+}\right), Y 2^{l o x} / / \mathrm{lox}$ control, GFPinjected control (GFP-Y2 ${ }^{\text {lox } / l o x}$ ), and Cre-injected hypothalamic Y2 receptor knockout (Cre-Y $2^{\text {lox/lox }}$ ). All mice were males, $15-17$ weeks of age. Measurements were taken 5 weeks after hypothalamic injection. Each micrograph is a representative sample. Bar represents $1 \mathrm{~mm}$.

Plasma concentrations of total calcium, leptin, free T4, IGF-1, and testosterone were unaffected by germline or conditional Y2 receptor knockout (Table 1). There was no significant effect of germline $\mathrm{Y} 2$ receptor knockout on corticosteronemia, but conditional Y2 receptor knockout mice had significantly greater corticosteronemia than did control mice injected with GFP- or Cre-expressing adenovirus (Table 1).

\section{Discussion}

Here we provide the first evidence that hypothalamic $\mathrm{Y} 2$ receptors are involved in a tonic inhibition of bone formation. The absence of detectable levels of Y receptor mRNAs in bone tissue is further evidence that this effect of $Y 2$ deficiency occurs by a central mechanism. It is noteworthy that the bone phenotype of conditional hypothalamic Y2 receptor knockout mice shown here is similar to that reported for mice deficient in leptin action (4). Trabecular bone density and the rate of bone mineralization and formation are increased in Y2 knockout mice, with no increase in osteoblast or osteoid surface, or osteoblast number. Thus deletion of hypothalamic Y2 receptors acts to release a tonic inhibition of the activity of trabecular osteoblast activity, increasing the rate of bone mineralization and formation twofold. In contrast with the $o b / o b$ and $d b / d b$ mice, in which osteoclast number was increased, osteoclast number in hypothalamic Y2 receptor knockout mice was reduced, suggesting different osteoclast regulation between the two models. However, osteoclast surface was not affected by Y2 deletion, suggesting an increase in osteoclast size in these knockouts. Such a change in osteoclast morphology is consistent with an increase in resorptive activity per cell $(21,22)$.

Both Y2 and leptin receptors are found on NPYexpressing neurons in the arcuate nucleus $(10,11)$. Deficiency of either the leptin receptor (1) or the Y2 receptor leads to increased NPY expression in the arcuate nucleus (data not shown), consistent with both receptors regulating bone formation by a common pathway. In support of this, the high-bone-density phenotype of $Y 2^{---}$mice and $o b / o b$ mice was not increased in $Y 2^{--}, o b / o b$ double knockout mice (unpublished observations from our group), indicating lack of additive, independent effects of the two gene deficiencies. It is not clear whether the high hypothalamic NPY a

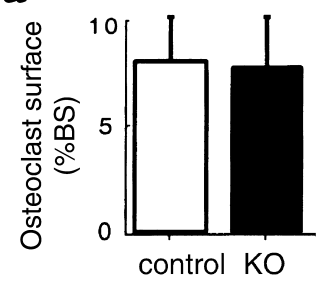

e

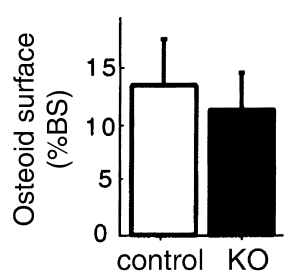

b

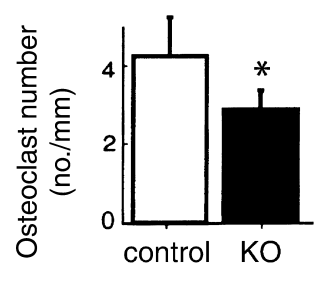

f

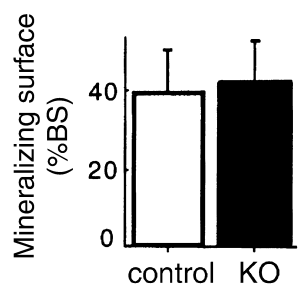

c

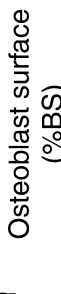

g

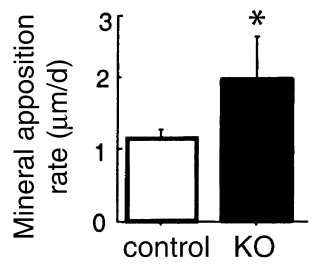

d

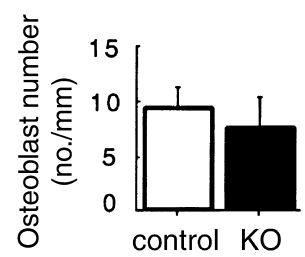

h

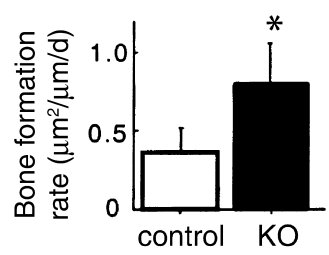

Figure 8

Effect of hypothalamus-specific Y2 receptor deletion on trabecular bone cell activity in the distal femoral metaphysis. Osteoclast surface (a), osteoclast number $(\mathbf{b})$, osteoblast surface $(\mathbf{c})$, osteoblast number $(\mathbf{d})$, osteoid surface $(\mathbf{e})$, mineralizing surface $(\mathbf{f})$, mineral apposition rate $(\mathbf{g})$, and bone formation rate $(\mathbf{h})$ of femurs from male $Y 2^{+/+}$Cre-adenovirus-injected or $Y 2^{10 x / l o x} \mathrm{GFP}$ - adenovirus-injected control mice (white bars) compared with $Y 2^{\text {lox } / \text { lox }}$ Cre-adenovirus-injected knockouts (KO, black bars) at 15-17 weeks of age. Values are mean \pm SD of five to seven mice per group. ${ }^{*} P<0.05$ versus controls. 

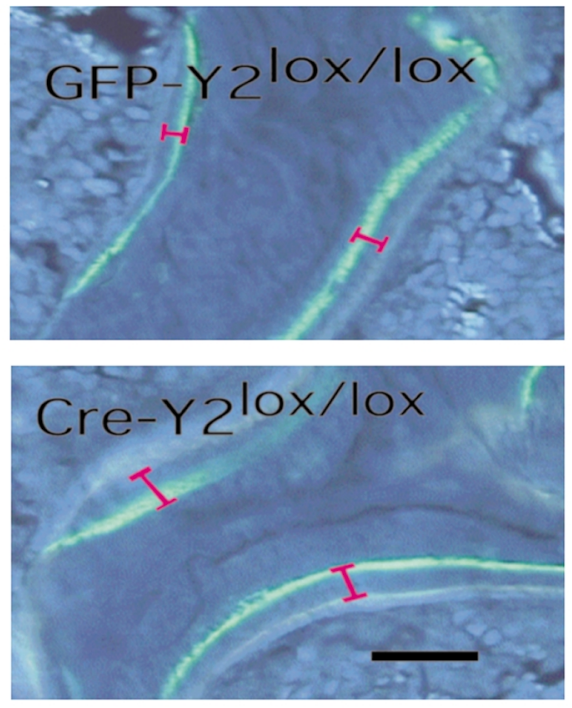

\section{Figure 9}

Effect of hypothalamus-specific $\mathrm{Y} 2$ receptor deletion on bone mineralization in the distal femoral metaphysis. Fluorescence micrographs of male GFP-adenovirus-injected $Y 2^{\text {lox } / l o x}$ control animals compared with Cre-adenovirus-injected $Y 2^{\text {lox } / \text { lox }}$ knockout mice at 15-17 weeks of age, showing the greater distance between the bands in knockout mice. Bar represents $1 \mathrm{~mm}$.

expression common to mice deficient in leptin action or $\mathrm{Y} 2$ receptors is causally related to the high bone density, because 28-day intracerebroventricular NPY infusion actually decreased bone density (though it probably also resulted in hyperleptinemia) (4). It is noteworthy that germline Y4 receptor knockout mice generated in our laboratory using the same strategies used for the Y2 receptor knockout, and maintained on the same background, do not present an increased bone forming phenotype. These data collectively suggest that $\mathrm{Y} 2$ receptor signaling specifically is important in regulating bone mass.

NPY in the hypothalamus influences peripheral tissues by neuroendocrine effects. Central NPY activates the hypothalamo-pituitary-corticotropic axis $(23,24)$ while inhibiting activity of the -thyrotropic $(24,25)$, -somatotropic $(24,26)$, and -gonadotropic axes $(24,26$, 27). It is likely that these effects are mediated by NPY projections to neurons that secrete releasing hormones into the pituitary portal system (24). This mechanism explains why deficiency of leptin action and the subsequently increased central NPY expression and secretion tonus not only contributes to massive obesity, but also leads to neuroendocrinological perturbations that would

\section{Table 1} concentrations be expected to decrease bone mass, namely hypercorticism, hypothyroid-ism (28-30), reduced somatotropic activity, and hypogonadism $(2,4)$. In contrast, germline or hypothalamus-specific Y2 receptor deletion did not induce any obvious endocrine imbalances that would have impacts on bone homeostasis. Knockout animals showed no significant change from controls in plasma concentrations of total calcium, leptin, free T4, IGF-1, or testosterone, and fertility was not impaired. The divergent changes in corticosteronemia seen in germline and conditional Y2 receptor knockout mice are not likely to explain the increased bone mass phenotype observed in both knockout models. These findings suggest that Y2 receptor deficiency does not influence bone formation via modulation of humoral factors.

Another mechanism by which central NPY can influence peripheral tissues is by alterations in autonomic neuronal activity. This is probably mediated by NPY projections from the hypothalamus to brain stem areas where sympathetic or parasympathetic neuronal activity is modulated (31). Whereas central Y1 and Y5 receptors are the most likely mediators of the strong stimulatory effect of NPY on food intake, Y2 receptors are known to be involved in the regulation of autonomic processes, such as central regulation of pancreatic secretion, gut motility $(32,33)$, and cardiovascular function (34). Notably, autonomic function is also disturbed in genetically obese rodents lacking leptin function $(35,36)$. Since rat bone tissue has recently been shown to contain autonomic fibers $(37,38)$, it is possible that alteration of autonomic activity in the bone presents a novel mechanism by which central regulators of bone homeostasis mediate their effects.

These data clearly indicate a major role of hypothalamic $\mathrm{Y} 2$ receptors in the regulation of bone mass. The rapid increase in bone volume in adult mice after central deletion of Y2 receptor suggests new possibilities for the prevention and anabolic treatment of osteoporosis.

Plasma total calcium, leptin, corticosterone (Cortico), free T4, IGF-1, and testosterone (Testost)

\begin{tabular}{lcccccc}
\hline & $Y 2^{+/+}$ & $Y 2^{+/-}$ & $Y 2^{-/-}$ & GFP-Y2lox/lox & Cre- $Y 2^{+/+}$ & Cre- $Y 2^{\text {lox/lox }}$ \\
Calcium $(\mathrm{mg} / \mathrm{dl})$ & $10.1 \pm 0.5$ & $10.0 \pm 0.4$ & $10.0 \pm 0.5$ & $10.4 \pm 1.6$ & $8.5 \pm 0.8$ & $9.0 \pm 0.4$ \\
& $(21)$ & $(15)$ & $(21)$ & $(5)$ & $(3)$ & $(11)$ \\
Leptin $(\mathrm{ng} / \mathrm{ml})$ & $6.6 \pm 2.4$ & $7.2 \pm 2.8$ & $6.2 \pm 1.6$ & $4.6 \pm 0.4$ & $\mathrm{ND}$ & $4.4 \pm 0.7$ \\
& $(6)$ & $(6)$ & $(6)$ & $(4)$ & & $(5)$ \\
Cortico $(\mathrm{ng} / \mathrm{ml})$ & $102 \pm 32$ & $48 \pm 14$ & $64 \pm 17$ & $54 \pm 23$ & $73 \pm 38$ & $139 \pm 18^{A}$ \\
& $(10)$ & $(19)$ & $(18)$ & $(5)$ & $(3)$ & $(11)$ \\
Free T4 $(\mathrm{pmol} / \mathrm{l})$ & $20.7 \pm 4.0$ & $16.4 \pm 2.9$ & $20.2 \pm 3.6$ & $19.2 \pm 1.1$ & 16.3 & $23.3 \pm 1.6$ \\
& $(4)$ & $(11)$ & $(8)$ & $(3)$ & $(1)$ & $(5)$ \\
IGF-1 $(\mathrm{ng} / \mathrm{ml})$ & $262 \pm 29$ & $\mathrm{ND}$ & $235 \pm 26$ & $320 \pm 58$ & $182 \pm 26$ & $238 \pm 36$ \\
& $(20)$ & & $(17)$ & $(5)$ & $(3)$ & $(11)$ \\
Testost $(\mathrm{nmol} / \mathrm{l})$ & $7.6 \pm 2.4$ & $5.1 \pm 2.5$ & $5.9 \pm 2.7$ & $\mathrm{ND}$ & $\mathrm{ND}$ & $\mathrm{ND}$ \\
& $(5)$ & $(10)$ & $(9)$ & & &
\end{tabular}

Data are presented as mean \pm SEM, with sample size indicated in parentheses. ${ }^{A} P<0.05$ versus GFP-adenovirus- or CRE-adenovirus-injected controls. ND, not determined. 


\section{Acknowledgments}

We thank I. Saito (Institute of Medical Science, University of Tokyo) for the Cre-adenovirus construct and Lee Carpenter for the GFP-expressing adenovirus. We thank Julie Ferguson for invaluable veterinary advice, and the staff of the Garvan Institute Biological Testing Facility. We are grateful to Sara Baker for expert technical assistance. Critical review of this manuscript by John Eisman, Peter Schofield, and Trevor Lewis was greatly appreciated. This research was supported by a Garvan Project Grant donated by Ray Williams, a block grant from the National Health and Medical Research Council of Australia Centre, a Human Frontier Science Program grant (RG0045/2000-B), and a Peter Doherty Post-Doctoral Fellowship (987122), to A. Sainsbury.

1. Stephens, T.W., et al. 1995. The role of neuropeptide Y in the antiobesity action of the obese gene product. Nature. 377:530-532.

2. Coleman, D.L. 1988. Classical diabetes models: past lessons and potential new therapies. In Frontiers in diabetes research. Lessons from animal diabetes II. E. Shafrir and A.E. Renold, editors. John Libbey \& Co. London, United Kingdom. 253-256.

3. Erickson, J.C., Hollopeter, G., and Palmiter, R.D. 1996. Attenuation of the obesity syndrome of ob/ob mice by the loss of neuropeptide Y. Science. 274:1704-1707.

4. Ducy, P., et al. 2000. Leptin inhibits bone formation through a hypothalamic relay: a central control of bone mass. Cell. 100:197-207.

5. Sainsbury, A., Cusin, I., Doyle, P., Rohner-Jeanrenaud, F., and Jeanrenaud, B. 1996. Intracerebroventricular administration of neuropeptide $\mathrm{Y}$ to normal rats increases obese gene expression in white adipose tissue. Diabetologia. 39:353-356.

6. Sainsbury, A., and Herzog, H. 2001. Inhibitory effects of central neuropeptide $\mathrm{Y}$ on the somatotropic and gonadotropic axes in male rats are independent of adrenal hormones. Peptides. 22:467-471.

7. Blomqvist, A.G., and Herzog, H. 1997. Y-receptor subtypes-how many more? Trends Neurosci. 20:294-298.

8. Parker, R.M., and Herzog, H. 1999. Regional distribution of Y-receptor subtype mRNAs in rat brain. Eur. J. Neurosci. 11:1431-1448.

9. Naveilhan, P., Neveu, I., Arenas, E., and Ernfors, P. 1998. Complementary and overlapping expression of $\mathrm{Y} 1, \mathrm{Y} 2$ and $\mathrm{Y} 5$ receptors in the developing and adult mouse nervous system. Neuroscience. 87:289-302.

10. Baskin, D.G., Breininger, J.F., and Schwartz, M.W. 1999. Leptin receptor mRNA identifies a subpopulation of neuropeptide $Y$ neurons activated by fasting in rat hypothalamus. Diabetes. 48:828-833.

11. Broberger, C., Landry, M., Wong, H., Walsh, J.N., and Hokfelt, T. 1997. Subtypes Y1 and Y2 of the neuropeptide Y receptor are respectively expressed in pro-opiomelanocortin- and neuropeptide-Y-containing neurons of the rat hypothalamic arcuate nucleus. Neuroendocrinology. 66:393-408.

12. King, P.J., Williams, G., Doods, H., and Widdowson, P.S. 2000. Effect of a selective neuropeptide Y Y(2) receptor antagonist, BIIE0246 on neuropeptide Y release. Eur. J. Pharmacol. 396:R1-R3.

13. Schwenk, F., Baron, U., and Rajewsky, K. 1995. A cre-transgenic mouse strain for the ubiquitous deletion of loxP- flanked gene segments including deletion in germ cells. Nucleic Acids Res. 23:5080-5081.

14. Franklin, K.B., and Paxinos, G. 1997. The mouse brain in stereotaxic coordinates. Academic Press. San Diego, California, USA. 35-55

15. Page, K. 1977. Bone and preparation of bone sections. In Theory and practice of histological techniques. J.D. Bancroft and A. Stevens, editors. Churchill Livingstone. London, United Kingdom. 223-248.

16. Parfitt, A.M., et al. 1983. Relationships between surface, volume, and thickness of iliac trabecular bone in aging and in osteoporosis. Implica- tions for the microanatomic and cellular mechanisms of bone loss. J. Clin. Invest. 72:1396-1409.

17. Parfitt, A.M., et al. 1987. Bone histomorphometry: standardization of nomenclature, symbols, and units. Report of the ASBMR Histomorphometry Nomenclature Committee. J. Bone Miner. Res. 2:595-610.

18. Hayman, A.R., Macary, P., Lehner, P.J., and Cox, T.M. 2001. Tartrateresistant acid phosphatase (Acp 5): identification in diverse human tissues and dendritic cells. J. Histochem. Cytochem. 49:675-684.

19. Gehlert, D.R., et al. 1996. Expression cloning of a human brain neuropeptide Y Y2 receptor. Mol. Pharmacol. 49:224-228.

20. Goumain, M., Voisin, T., Lorinet, A.M., and Laburthe, M. 1998. Identification and distribution of mRNA encoding the Y1, Y2, Y4, and Y5 receptors for peptides of the PP-fold family in the rat intestine and colon. Biochem. Biophys. Res. Commun. 247:52-56.

21. Piper, K., Boyde, A., and Jones, S.J. 1995. Volumes of chick and rat osteoclasts cultured on glass. Calcified Tissue Int. 56:382-389.

22. Piper, K., Boyde, A., and Jones, S.J. 1992. The relationship between the number of nuclei of an osteoclast and its resorptive capability in vitro. Anat. Embryol. 186:291-299.

23. Sainsbury, A., et al. 1997. Chronic central neuropeptide Y infusion in normal rats: status of the hypothalamo-pituitary-adrenal axis, and vagal mediation of hyperinsulinaemia. Diabetologia. 40:1269-1277.

24. McDonald, J.K., and Koenig, J.I. 1993. Neuropeptide Y actions on reproductive and endocrine functions. In The biology of neuropeptide $Y$ and related peptides. W.F. Colmers and C. Wahlestedt, editors. Humana Press. Totowa, New Jersey, USA. 419-456.

25. Fekete, C., et al. 2001. Neuropeptide $Y$ has a central inhibitory action on the hypothalamic-pituitary-thyroid axis. Endocrinology. 142:2606-2613.

26. Pierroz, D.D., Catzeflis, C., Aebi, A.C., Rivier, J.E., and Aubert, M.L. 1996. Chronic administration of neuropeptide $Y$ into the lateral ventricle inhibits both the pituitary-testicular axis and growth hormone and insulin-like growth factor I secretion in intact adult male rats. Endocrinology. 137:3-12.

27. Clark, J.T., Kalra, P.S., and Kalra, S.P. 1985. Neuropeptide Y stimulates feeding but inhibits sexual behavior in rats. Endocrinology. 117:2435-2442.

28. Durbin-Naltchayan, S., Bouhnik, J., and Michel, R. 1983. Thyroid status in the obese syndrome of rats. Horm. Metab. Res. 15:547-549.

29. Chomard, P., Beltramo, J.L., Ben Cheikh, R., and Autissier, N. 1994. Changes in thyroid hormone and thyrotrophin in the serum and thyroid glands of developing genetically obese male and female Zucker rats. J. Endocrinol. 142:317-324.

30. Kaplan, M.M., and Young, J.B. 1987. Abnormal thyroid hormone deiodination in tissues of $\mathrm{ob} / \mathrm{ob}$ and $\mathrm{db} / \mathrm{db}$ obese mice. Endocrinology. 120:886-893.

31. Saper, C.B., Loewy, A.D., Swanson, L.W., and Cowan, W.M. 1976. Direct hypothalamo-autonomic connections. Brain Res. 117:305-312.

32. Chen, C.H., Stephens, R.L., Jr., and Rogers, R.C. 1997. PYY and NPY: control of gastric motility via action on Y1 and Y2 receptors in the DVC. Neurogastroenterol. Motil. 9:109-116.

33. Fujimiya, M., et al. 2000. Neuropeptide Y induces fasted pattern of duodenal motility via $\mathrm{Y}(2)$ receptors in conscious fed rats. Am. J. Physiol. 278:G32-G38.

34. Mahns, D.A., Lacroix, J.S., and Potter, E.K. 1998. Inhibition of vagal vasodilatation by a selective neuropeptide Y Y2 receptor agonist in the bronchial circulation of anaesthetised dogs. J. Auton. Nerv. Syst. 73:80-85.

35. Rohner-Jeanrenaud, F. 1995. A neuroendocrine reappraisal of the dualcentre hypothesis: its implications for obesity and insulin resistance. Int. J. Obes. 19:517-534.

36. Bray, G.A. 1990. The MONA LISA hypothesis. Most obesities known are low in sympathetic activity. In Progress in obesity research 1990. Y. Oomura, S. Tarui, S. Inoue, and T. Shimazu, editors. John Libbey and Co. London, United Kingdom. 61-66.

37. Schwab, W., Bilgicyildirim, A., and Funk, R.H. 1997. Microtopography of the autonomic nerves in the rat knee: a fluorescence microscopic study. Anat. Rec. 247:109-118.

38. Sisask, G., Bjurholm, A., Ahmed, M., and Kreicbergs, A. 1996. The development of autonomic innervation in bone and joints of the rat. J. Auton. Nerv. Syst. 59:27-33. 